\title{
Formulation and Pharmacological Studies of Leaves of Moringa (Moringa oleifera), a Novel Hepatoprotection in Oral Drug Formulations
}

\author{
Aristianti Aristianti ${ }^{1}$, Nurkhaeri Nurkhaeri ${ }^{2}$, Vanny Y. Tandiarrang ${ }^{2}$, Akbar Awaluddin $^{3}$, Lukman Muslimin $^{4 *}$
}

${ }^{1}$ Department of Pharmacology, Faculty of Medicine, Hasanuddin University, Makassar, Indonesia; ${ }^{2}$ Department of Pharmaceutical Technology, Sekolah Tinggi Ilmu Farmasi Makassar, Makassar, Indonesia; ${ }^{3}$ Department of Pharmacology, Sekolah Tinggi IImu Farmasi Makassar, Makassar, Indonesia; ${ }^{4}$ Department of Pharmaceutical Chemistry, Sekolah Tinggi Ilmu Farmasi Makassar, Makassar, Indonesia

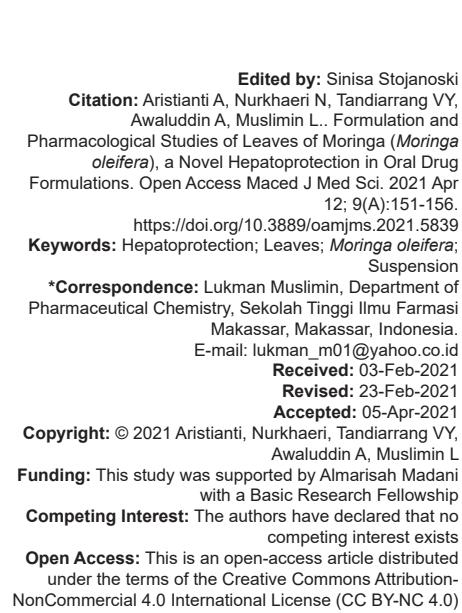

\section{Introduction}

Tuberculosis (TB), caused by Mycobacterium tuberculosis, is one of the main causes of death among infectious diseases worldwide. Even though TB was controlled in the past, cases of morbidity and mortality tend to increase again. Lack of public health awareness and uncontrolled antibiotics are the main problems. Globally, a total of 1.4 million people died from TB in 2019 (including 208000 people with human immunodeficiency virus, HIV) [1]. Indonesia remains among the world's third burden countries, with nearly 842,000 incidents in 2017 . The mortality rate for that year was 107,000 deaths, as $75 \%$ of TB survivors are from the productive age group (15-50 years old) [2].

Isoniazid is a main antibiotic drug to treat TB. In the treatment of TB, isoniazid can be combined with other antibiotics, ethambutol, pyrazinamide, or rifampicin. In addition, isoniazid is also used in the treatment of latent TB infection (underdeveloped) [3], [4]. This condition can be experienced by someone with a history of close contact with people with active TB, people with positive tuberculin skin test results, people with HIV, or people with pulmonary fibrosis [5].

Being the first-line drug used for TB chemotherapy, isoniazid is known to be associated with hepatotoxicity [6]. Isoniazid produces severe idiosyncratic hepatotoxicity [7]. The liver is the main site for drug metabolism which is also called biotransformation, and the end result of this reaction is a substance that is inactive and more soluble in water so that it is quickly excreted through bile and urine [8], [9]. Isoniazid is hydrazide that is readily oxidized by hepatocytes. Two metabolites have been proposed to be responsible for isoniazid-induced liver injury, acetyl hydrazine, and hydrazine (Figure 1). Liver injury is characterized by the elevation of hepatic biochemical such as liver transferase enzymes (e.g., serum glutamate oxaloacetate transaminase [SGOT] and serum glutamate pyruvate transaminase [SGPT]), the formation of reactive oxygen species, an increase of lipid peroxidation, and superoxide dismutase [10], [11]. Some studies reported 


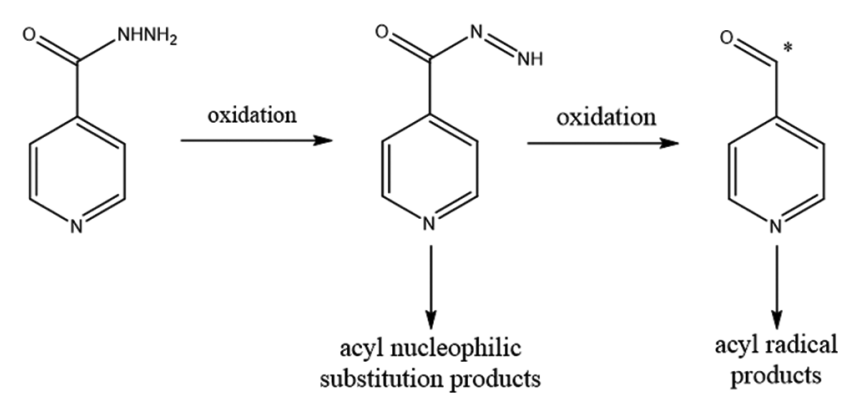

Figure 1: A schematic representation of isoniazid metabolism

that the administration of drugs or substances that can fight oxidative stress could protect the liver from damage.

Moringa oleifera, commonly known as moringa, belongs to the family of Moringaceae is widely distributed in South East Asia. Conventionally, in some countries like Indonesia, M. oleifera has long been widely used to relieve various diseases, such as diabetes, antioxidants, antiinflammation, and anticancer [12], [13], [14]. It is reported that the $M$. oleifera contains many phytoconstituents such as flavonoids, alkaloids, saponin, and phenolic acid [15]. Flavonoids will inhibit multifactorial against oxidative stress. In addition, anti-inflammatory and analgesic flavonoids have a protective mechanism [16]. Flavonoids play a role in protecting of hepatoma cells through glutathione reductase activity and increasing antioxidant enzymes that related in hepatoprotection [17]. Based on the research of Ekundina et al. was found that $M$. oleifera leaves extract which can function as a hepatoprotection at dose of $400 \mathrm{mg} / \mathrm{kg} \mathrm{BW} \mathrm{[18].} \mathrm{Doe} \mathrm{to} \mathrm{undissolved} \mathrm{in}$ water, $M$. oleifera leaves extract will be formulated in a suspension using sodimum carboxymethyl cellulose (Na-CMC), at three different concentrations, was 0.1 , 0.5 , and $1.0 \% \mathrm{w} / \mathrm{v}$.

Therefore, the objectives of the present study were to formulate $M$. oleifera leaves extract in suspension. The suspensions were characterized, and the in vivo hepatoprotection activity was performed to ensure the pharmacological properties of the extract.

\section{Materials and Methods}

\section{Materials}

$\mathrm{Na}-\mathrm{CMC}$, propilenglikol, sodium benzoate $(\mathrm{Na}$ benzoate), sorbitol, oleum menthae, and aquadest were pharmaceutical grade.

\section{Collection and extraction procedure}

The leaves of $M$. oleifera were collected from Makassar in November 2018. Identification and authentication of the leaves were made by the Indonesia Institute of Science Research Center for Biology, Bogor,
Indonesia. The fresh leaves were sorted and rinsed under the tap water to eliminate unwanted materials and wash again with aquadest. The leaves were air dried for 3 days and powder. Approximately $500 \mathrm{~g}$ of dried powder was added to $3.0 \mathrm{~L}$ of $70 \%$ ethanol in a macerator and was kept at room temperature for 3 days in the shade while stirring occasionally. The ethanol layer was filtrated and concentrated in a vacuum in a rotary evaporator (Buchi R-100), and the residue was dried in desiccators over silica.

\section{Preparation of suspension}

The leaves extract of $M$. oleifera and propilenglikol was ground homogeneously using a mortar and stamper (Mix A). Na-CMC was dispersed in a glass beaker with $10.0 \mathrm{~mL}$ hot water $\left(70^{\circ} \mathrm{C}\right)$ and stirred using a magnetic stirrer until homogeneous (Mix B). Then, the Mix A was put into the Mix B, homogenous and added sorbitol. Na benzoate was dissolved with enough aquadest and added to thoroughly solution. Enough the volume to $100.0 \mathrm{ml}$ with aquadest, add the oleum menthae flavor, and then put the suspension into a plastic bottle. Table 1 shows the formulations studied.

Table 1: Trials for the development of suspension formulation

\begin{tabular}{llll}
\hline Ingredients & Quantity $(\mathrm{w} / \mathrm{v} \%)$ & & \\
\cline { 2 - 4 } & $\mathrm{F} 1$ & $\mathrm{~F} 2$ & $\mathrm{~F} 3$ \\
\hline Extract & 1.0 & 1.0 & 1.0 \\
Na-CMC & 0.1 & 0.5 & 1.0 \\
Propilenglikol & 10.0 & 10.0 & 10.0 \\
Na benzoate & 0.1 & 0.1 & 0.1 \\
Sorbitol & 70.0 & 70.0 & 70.0 \\
Oleum menthae & q.S & q.S & q.S \\
Aquadest & till $100.0 \mathrm{~mL}$ & till $100.0 \mathrm{~mL}$ & till $100.0 \mathrm{~mL}$ \\
\hline
\end{tabular}

\section{Physicochemical evaluation}

The developed syrup was assessed for different physicochemical parameters such as physical appearance including appearance, color, odor, and taste.

\section{$\mathrm{pH}$}

The $\mathrm{pH}$ value represents the acidify or alkalinity of a solution. The $\mathrm{pH}$ of suspension was determined by a digital $\mathrm{pH}$ meter using a glass electrode. The apparatus was allowed to stabilize and calibrated using buffer. The suspension is placed on a $\mathrm{pH}$ meter and recorded when there is no fluctuation in the $\mathrm{pH}$ meter.

\section{Density}

Wash thoroughly the $50 \mathrm{~mL}$ volumetric flash and dry in oven to a fixed weight (W1). The oral suspension was added up to the mark and weighed (W2). Calculated the density accordingly.

$$
\text { Density }(\mathrm{g} / \mathrm{mL})=\frac{(\mathrm{W} 2-\mathrm{W} 1)}{50}
$$




\section{Viscosity}

The viscosity of suspension formulations was determined using Brookfield Viscometer (Brookfield Engineering Laboratories, USA).

\section{Re-dispersibility test}

The re-dispersibility of the suspensions was checked by inverting the cylinder upside down until there was no sediment at the bottom of the cylinder appear.

\section{Sedimentation volume}

Suspension of each formulation was kept standing undisturbed at room temperature. The volume of sediment was noted, and the sedimentation ratio was calculated.

\section{Stability studies of optimized suspense formulation}

After preparation of the suspension preparation, a physical evaluation of the preparation is performed immediately. A side from doing physical evaluation performed physical stability test in which three formula suspension stored at low temperature $\left(5^{\circ} \mathrm{C} \pm 2^{\circ} \mathrm{C}\right)$, room temperature $\left(35^{\circ} \mathrm{C} \pm 2^{\circ} \mathrm{C}\right), 75 \%$ relative active humidity $(\mathrm{RH})$ for $12 \mathrm{~h}$ for seven cycles of each and then observed the physical evaluation.

\section{Hepatoprotective activity}

\section{Experimental design and animal grouping}

Male Wistar rats were procured from the department of pharmacology, Sekolah Tinggi IImu Farmasi Makassar, Indonesia. The animals were provided with controlled environmental conditions (temperature $24^{\circ} \mathrm{C} \pm 2{ }^{\circ} \mathrm{C}$; relative humidity $40-60 \%$; and $12 / 12$ light/dark cycle) with the standard commercial pellets and water ad libitum. All the experiments were performed with the permission from Institutional Animal Ethics Committee No. UMI1021812609. The male Wistar rats weighing 180-200 g was used for the study. Animals were divided into three groups ( $n=3 /$ group) as follows: Normal control rats received aquadest 5.0 $\mathrm{mL} / \mathrm{kg}$ BW for 28 days. Negative control rats received aquadest for 5 days and followed by isoniazid $50.0 \mathrm{mg} /$ $\mathrm{kg}$ BW once a day till day $28^{\text {th }}$. The treatment group received test suspension (F2) $400 \mathrm{mg} / \mathrm{kg} \mathrm{BW}$ per oral for 28 days once a day and treated isoniazid $50.0 \mathrm{mg} /$ $\mathrm{kg} \mathrm{BW}$ once a day-on-day $6^{\text {th }}$ until the experiment was done. Two hours after respective drug treatments, rats were anesthetized using diethyl ether inhalation jar. Blood was collected through orbital puncture, and the serum was separated.

\section{biochemical}

\section{Determination of key liver function}

Liver function biochemical markers, SGOT, and SGPT have been evaluated in the serum obtained from the experimental animals using IFFC mod. liquiUV Humazym Test Kit (Human).

\section{Histopathological studies}

Livers excised after sacrificing the animals were immediately washed with phosphate-buffered saline $\mathrm{pH} 7.4$ and fixed in $10 \%$ buffered formalin. They were then dehydrated through graded alcohol series (70, 90, and 96\%), cleared in xylene, and embedded in paraffin wax. Sections of 5-6 m thickness were cut using microtome and stained with hematoxylin-eosin (HE). The histopathological changes were examined under the microscope (Olympus, Japan).

\section{Data Analysis}

Data were presented as mean \pm standard deviation (mean \pm SD). Wilcoxon non-parametric test was used for examining the physical evaluation and one-way ANOVA, followed by Tukey's post-hoc test for examining the biological enzymatic by value with being less than $p<0.05$.

\section{Results}

The leaves extract of $M$. oleifera suspensions (50 mg/5 mL) was prepared the $\mathrm{Na}-\mathrm{CMC}$ at different levels, that is, $0.1,0.5$, and $1 \% \mathrm{w} / \mathrm{v}$. These suspensions were assessed for their color, appearance, odor, and taste were observed using the appropriate sense organs and presented in Table 2. All suspensions have a special color of $M$. oleifera extract, a special character of the suspension which has a turbidimetric solution, a typical odor of $M$. oleifera extract, and the tastes sweet due to the addition of sugar. All the suspension shows good character and acceptable.

Table 2: Organoleptic evaluation of suspension of the basic of different parameters. All the measurements were done in triplicate $(n=3)$

\begin{tabular}{lll}
\hline Formula & Before accelerated test & Before accelerated test \\
\hline F1 & Color & Dark green \\
F2 & Dark green & Dark green \\
F3 & Dark green & Dark green \\
& Dark green & \\
F1 & Appearance & Turbid solution \\
F2 & Turbid solution & Turbid solution \\
F3 & Turbid solution & Turbid solution \\
& Turbid solution & \\
F1 & Odor & Characteristic \\
F2 & Characteristic & Characteristic \\
F3 & Characteristic & Characteristic \\
& Characteristic & \\
F1 & Taste & Sweet \\
F2 & Sweet & Sweet \\
F3 & Sweet & Sweet \\
\hline
\end{tabular}



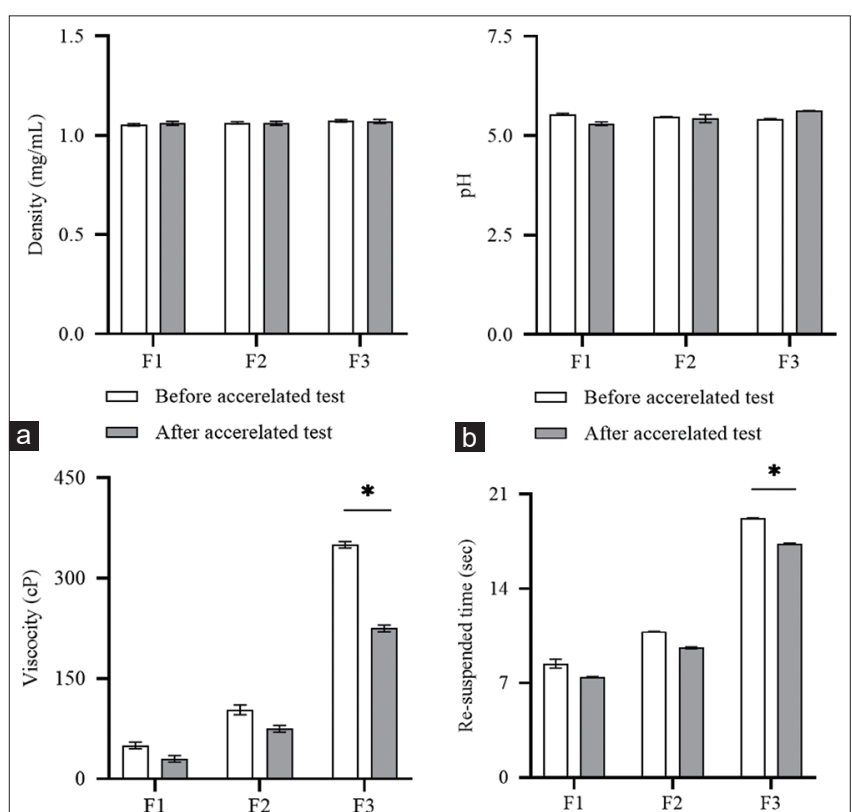

b $\square$ After accerelated test

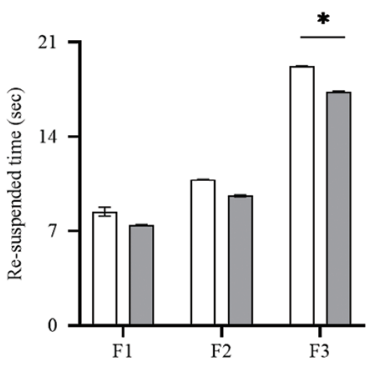

$\square$ Before accerelated test

d

C

$\square$ Before accerelated tes

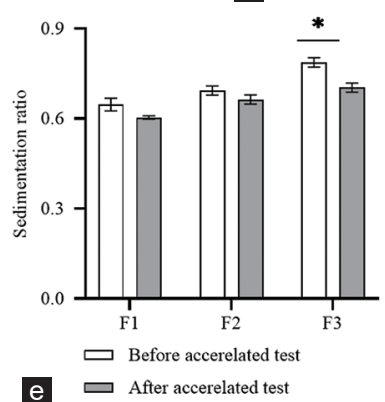

Figure 2: Effect of concentration of suspending agent on density (a); $\mathrm{pH}$ (b); viscosity (c); re-suspended time (d); sedimentation ratio (e). *Superscript indicates significance difference $(p<0.05)$ using onesample Wilcoxon signed-rank test. All the measurements were done in triplicate $(n=3)$

Accelerated stability studies were performed to determine the stability of the suspension under extreme conditions. No significant difference in all parameters was observed in F1 and F2; however, significant $(p>0.05)$ changes parameters in viscosity, re-dispersibility, and sedimentation ratio at $\mathrm{F} 3$ (Figure 2). All the suspensions showed $\mathrm{pH}$ range 5.25-5.62 and met the requirement. Viscosity value is directly proportional to the amount of suspending material used. This is in accordance with the theory that the higher the $\mathrm{Na}-\mathrm{CMC}$ concentration is used; the viscosity will increase due to the increasing number of Na-CMC molecules that absorb water to be able to expand in a dispersion. The conditions for a good suspension viscosity are 37-396 cP. Figure 2 showed that all suspension meets the requirement; however, there is a very extreme change in viscosity at F3 ( $p$ $>0.05$ ), and only F2 showed a good flow rate. The suspensions were shaken at the end of $24 \mathrm{~h}$ for several days to assess re-suspension of the formulation. It was observed that F1 and F2 showed quick settling of particles. However, suspensions containing $\mathrm{Na}-\mathrm{CMC}$ at $1 \%(\mathrm{~F} 3)$ concentration showed gradual and slow settling of particles, however, a significant $(p>0.05)$ change after the accelerated test. The results are in conformation with the density and viscosity study. The results obtained so far therefore have indicated that use $0.5 \%$ of $\mathrm{Na}-\mathrm{CMC}$ as suspension agent has a good physical parameter and continued for in vivo studies.

The illustration of liver function can be known through quantitative biochemical markers such as SGOT and SGPT. The rats administrated with isoniazid $(50.0 \mathrm{mg} / \mathrm{kg})$ caused significant liver damage and necrosis of hepatic cells as evidenced by the elevated serum hepatic biomarker, SGOT, and SGPT (Figure 3). The level of enzyme markers SGOT and SGPT in normal rats was found to be $120.17 \pm 10.59 \mathrm{U} / \mathrm{mL}$ and $56.68 \pm 5.13 \mathrm{U} / \mathrm{mL}$, respectively; expected, isoniazid intoxication made their elevation to 2.13 and 1.95 -fold increment to $233.26 \pm 15.70 \mathrm{U} / \mathrm{mL}$ and $97.34 \pm 4.19 \mathrm{U} / \mathrm{mL}$. This indicates hepatic injury and loss of structural integrity. Pre-treatment with stable suspension (F2) $400 \mathrm{mg} / \mathrm{kg}$ BW significantly $(p<0.05)$ reduced their elevations in $213.93 \pm 29.14 \mathrm{U} / \mathrm{mL}$ and $175.96 \pm 24.11 \mathrm{U} / \mathrm{mL}$ for SGOT and SGPT, respectively. Treatments with ethanol leaves extract of $M$. oleifera that formulated into suspension indicate the stabilization of plasma membrane as well as repair of hepatic tissue damage caused by isoniazid.

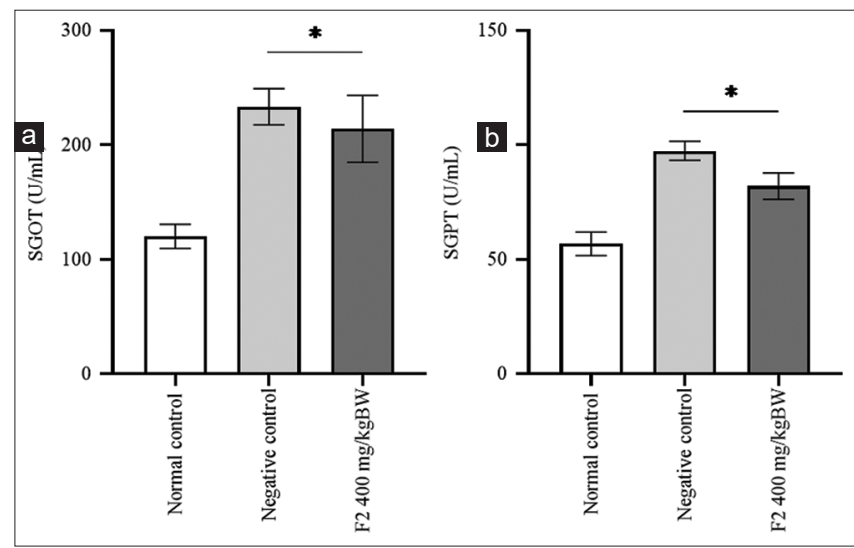

Figure 3: Effect of concentration of stable suspension (F2) on: SGOT (a); SGPT (b). *Superscript indicates significance difference $(p<0.05)$ with control negative using one-way ANOVA followed by Tukey's post hoc test. All the measurements were done in triplicate $(n=3)$

The main aim of histopathological study is to understand how tissue is organized at all structural levels. The histopathological liver sections of rats from the experimental groups are shown in Figure 4. The negative control showed fat degeneration, congestion, and necrosis. This indicates a severe damage caused by isoniazid. Pre-treatment with stable suspension (F2) at dose $400 \mathrm{mg} / \mathrm{kg} \mathrm{BW}$ in isoniazid intoxicated rats showed hepatocytes' recovery from degeneration, congestion, and necrosis. Even though such damage, hydropic degeneration was still visible. 


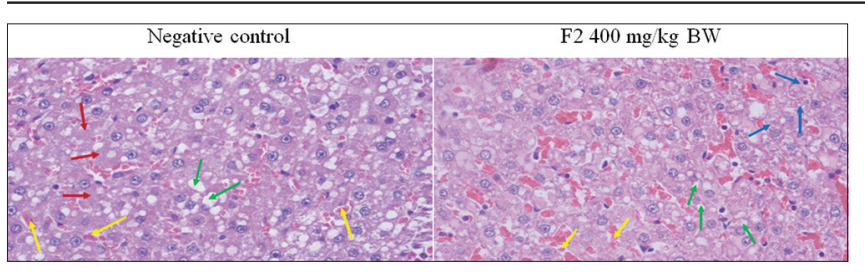

Figure 4: Photomicrographs of hematoxylin-eosin stained histological sections of negative control and F2 $400 \mathrm{mg} / \mathrm{kg} \mathrm{BW}$ treated rats liver The arrow indicates: Green = fat degeneration; blue = hydropic degeneration; yellow = congestion; red = necrosis

\section{Discussion}

Since thousands of years ago, plant medicines play an important role for the treatment of various diseases in human life. Some of them have been analyzed and scientifically validated for their potentials. Here, the authors designed the experiments to examine the hepatoprotective activity of ethanol leaves extract of $M$. oleifera that formulated into suspension with $\mathrm{Na}-\mathrm{CMC}$ as suspension agent at three concentrations for their development into safe natural drug candidates.

$\mathrm{Na}-\mathrm{CMC}$ as modified starches has played a major role in the food and pharmaceutical industry in the past few decades. Modified starch possesses some unique properties, not found in natural starches. For examples are $\mathrm{pH}$ stability, predictable rheological profiles, solubility in unheated water, and safe [19], [20]. The difference of Na-CMC concentration caused different viscosities of each formula since $\mathrm{Na}-\mathrm{CMC}$ has a role in viscosity value of solution. During storage, the suspension will undergo sediment. Hence, it must be easily dispersed again by shaking to ensure the uniform of the dose. If sediments remain cannot be dispersed after shaking vigorously for a short time, the system is described as caked [21]. All the four formulations of $\mathrm{Na}-\mathrm{CMC}$ were found to be easily re-dispersible, but F3 needs much time for it.

Suspensions are the least stable dosage form due to sedimentation and cake formation. As the viscosity increases, the sediment settling rate also decreases, thus, the dissipated phase settles at a slower rate and remains dispersed for a long time resulting in higher stability in the suspension. Less viscous suspensions tend to flow more easily and get out of the bottle than the more viscous ones, hence study of viscosity and density are very important to understand the stability of suspensions [22]. In this study, viscosity of suspensions was studied in Brookefield viscometer. The results indicate that as the amounts of the suspending agent increases, viscosity also increases gradually. To avoid irritation on gastrointestinal tract, all oral administration must meet the requirement ranging from circa 3.0 to $6.8 \mathrm{pH}$ units [23]. Lower $\mathrm{pH}$ can irritate upper gastric, skin could dissolve, causing great damage, as well as
$\mathrm{pH}$ greater than 10. Knowing the $\mathrm{pH}$ of the substances is very important for safety against any chemical product [24].

To evaluate the effectivity, $\mathrm{F} 2$ as stable suspension was tested for its hepatoprotection effect against isoniazid induced liver injury in Wistar rats. Isoniazid, isonicotinic acid hydrazide, is an important first-line antibiotic used for the treatment or prevention of TB. One of the crucial problems in isoniazid is hepatotoxic [7]. In the clinical, patient characteristics of isoniazid induced liver injury are fairly typical for idiosyncratic drug-induced liver injury and include malaise, fatigue, nausea, and vomiting. Increasing the level of hepatocyte injury biomarker such as SGOT and SGPT was observed in blood as well as a change in liver histopathology [25], [26] as representative in negative control.

Pre-treatment with ethanol extract of $M$. oleifera leaves that formulated into suspension $400 \mathrm{mg} / \mathrm{kg}$ BW for 28 days significant protection against isoniazid-induced hepatic damage. This is indicated by a decrease in levels of SGOT and SGPT. Decreases in SGOT and SGPT activities, improvements in hepatic histopathology of rats treated with F2. The hepatocyte cells of F2 indicate the recovery of hepatocytes from degeneration, congestion, and necrosis. In addition, there was hydropic degeneration still observed. The possible mechanism of action behind the hepatoprotection activity of $M$. oleifera in this model may be associated with the antioxidant effect. Metabolizing in liver resulting toxic metabolites of isoniazid, mainly CYP 2E1-mediated reactive oxidative products of hydrazine and acetylhydrazine, play a crucial role in liver injury. Addition of antioxidant can scavenge the reactive metabolite. The flavonoid group, quercetin, and rutin contained in $M$. oleifera leaves have an antioxidant effect. Quercetin able to capture or neutralize free radicals associated with phenolic $\mathrm{OH}$ groups that can repair the state of damaged tissue and inhibit the inflammatory process. Other compounds b-carotene of $M$. oleifera is responsible for the hepatoprotective activity. $\beta$-Carotene exhibits a good radical-trapping free radical, reduces oxidative stress, and regulates the lipid metabolism of hepatocytes [27].

\section{Conclusion}

The data provided in this study demonstrate that ethanol extract of $M$. oleifera leaves can be formulated into stable suspension and meet good pharmaceutical properties. Using $\mathrm{Na}-\mathrm{CMC}$ at $0.5 \%$ concentration as suspension agent was the best choice for $1 \%$ of the extract, even though the microbiological stability of oral suspensions for 
further experiments. Finally, the suspension is proven to be able to protect the liver from damage, so it is recommended as a supportive supplement for TC that receiving isoniazid.

\section{References}

1. World Health Organization. Tuberculosis. Geneva: World Health Organization; 2019. Available from: https://www.who.int/newsroom/fact-sheets/detail/tuberculosis. [Last accessed on 2021 Jan 30].

2. Susilawati TN, Larasati R. A recent update of the diagnostic methods for tuberculosis and their applicability in indonesia: A narrative review. Med J Indones. 2019;28(3):284-91. https://doi. org $/ 10.13181 / \mathrm{mji}$. v28i3.2589

3. Sotgiu G, Centis R, D'Ambrosio L, Migliori GB. Tuberculosis treatment and drug regimens. Cold Spring Harb Perspect Med. 2015;5(5):a017822. https://doi.org/10.1101/cshperspect. a017822

\section{PMid:25573773}

4. Arbex MA, Varella Mde C, Siqueira HR, Mello FA Antituberculosis drugs: Drug interactions, adverse effects, and use in special situations. Part 1: First-line drugs. J Bras Pneumol. 2010;36(5):626-40.

PMid:21085830

5. Geremew D, Endalamaw A, Negash M, Eshetie S, Tessema B. The protective effect of isoniazid preventive therapy on tuberculosis incidence among HIV positive patients receiving ART in Ethiopian settings: A meta-analysis. BMC Infect Dis. 2019;19(1):405. https://doi.org/10.1186/s12879-019-4031-2 PMid:31077133

6. Yadav B, Gunnam A, Thipparaboina R, Nangia AK, Shastri NR. Hepatoprotective cocrystals of isoniazid: Synthesis, solid state characterization, and hepatotoxicity studies. Cryst Growth Des. 2019;19(9):5161-72. https://doi.org/10.1021/acs.cgd.9b00541

7. Metushi I, Uetrecht J, Phillips E. Mechanism of isoniazidinduced hepatotoxicity: Then and now. $\mathrm{Br} \mathrm{J}$ Clin Pharmacol. 2016;81(6):1030-6.

PMid:26773235

8. Almazroo OA, Miah MK, Venkataramanan R. Drug metabolism in the liver. Clin Liver Dis. 2017;21(1):1-20. https://doi.org/10.1111/ bcp. 12885

\section{PMid:27842765}

9. Underhill GH, Khetani SR. Advances in engineered human liver platforms for drug metabolism studies. Drug Metab Dispos. 2018;46(11):1626-37. https://doi.org/10.1124/dmd.118.083295 PMid:30135245

10. Biswas A, Santra S, Bishnu D, Dhali GK, Chowdhury A, Santra A Isoniazid and rifampicin produce hepatic fibrosis through an oxidative stress-dependent mechanism. Int J Hepatol. 2020;2020:6987295. https://doi.org/10.1155/2020/6987295 PMid:32373368

11. Cheng DL, Zhu N, Li CL, Lv WF, Fang WW, Liu Y, et al. Significance of malondialdehyde, superoxide dismutase and endotoxin levels in Budd-Chiari syndrome in patients and a rat model. Exp Ther Med. 2018;16(6):5227-35. https://doi.org/10.3892/etm.2018.6835 PMid:30542478

12. Villarruel-López A, López-de la Mora DA, Vázquez-Paulino $O D$, Puebla-Mora AG, Torres-Vitela MR, Guerrero-Quiroz LA, et al. Effect of Moringa oleifera consumption on diabetic rats. BMC
Complement Altern Med. 2018;18:127. https://doi.org/10.1186/ s12906-018-2180-2

PMid:29636032

13. Jahan IA, Hossain MH, Ahmed KS, Sultana Z, Biswas PK, Nada K. Antioxidant activity of Moringa oleifera seed extracts. Orient Pharm Exp Med. 2018;18(4):299-307. https://doi. org/10.1007/s13596-018-0333-y

14. Al-Asmari AK, Albalawi SM, Athar MT, Khan AQ, Al-Shahrani H, Islam M. Moringa oleifera as an anti-cancer agent against breast and colorectal cancer cell lines. PloS One. 2015;10:e0135814. https://doi.org/10.1371/journal.pone.0135814 PMid:26288313

15. Xu YB, Chen GL, Guo MQ. Antioxidant and anti-inflammatory activities of the crude extracts of Moringa oleifera from Kenya and their correlations with flavonoids. Antioxidants (Basel). 2019;8:296. https://doi.org/10.3390/antiox8080296 PMid:31404978

16. Panche AN, Diwan AD, Chandra SR. Flavonoids: An overview. J Nutr Sci. 2016;5:e47. PMid:28620474

17. Nguyen TP, Tran CL, Vuong CH, Do TH, Le TD, Mai DT, et al Flavonoids with hepatoprotective activity from the leaves of Cleome viscosa L. Nat Prod Res. 2017;31(22):2587-92. https:// doi.org/10.1080/14786419.2017.1283497 PMid:28135851

18. Ekundina VO, Ebeye OA, Oladele AA, Osham GO. Hepatotoxic and nephrotoxic effects of Moringa oleifera leaves extract in adult Wistar rats. J Nat Sci Res. 2015;5(3):110-7.

19. Kittipongpatana O, Sirithunyalug J. Development of suspending agent from sodium carboxymethyl mungbean starches. Drug Dev Ind Pharm. 2006;32(7):809-20. https://doi. org/10.1080/03639040500529978

PMid: 16908418

20. Kittipongpatana OS, Burapadaja S, Kittipongpatana N Carboxymethyl mungbean starch as a new pharmaceutical gelling agent for topical preparation. Drug Dev Ind Pharm. 2009;35(1):34-42. https://doi.org/10.1080/03639040802144229 PMid: 18720150

21. Doye $P$, Mena $T$, Das $N$. Formulation and bio-availability parameters of pharmaceutical suspension. Int J Curr Pharm Res. 2017;9(3):8-14. https://doi.org/10.22159/ijcpr.2017.v9i3.18892

22. Kumar R, Rajarajeshwari N, Swamy VB. Isolation and evaluation of Borassus flabellifer mucilage as a natural suspending agent. Int J Pharmtech Res. 2012;4(4):1614-30.

23. Ahn JY, Kim JM, Jeong TS, Kim S. A study on the effect of syrup form medicines for children on intraoral $\mathrm{pH}$. J Korean Acad Pediatr Dent. 2007;34(4):590-8.

24. Patel D, Bertz R, Ren S, Boulton DW, Någård M. Asystematic review of gastric acid-reducing agent-mediated drug-drug interactions with orally administered medications. Clin Pharmacokinet. 2020;59(4):447-62. https://doi.org/10.1007/s40262-019-00844-3 PMid:31788764

25. Wang $\mathrm{P}$, Pradhan $\mathrm{K}$, Zhong $\mathrm{X}-\mathrm{b}$, Ma $\mathrm{X}$. Isoniazid metabolism and hepatotoxicity. Acta Pharm Sin B. 2016;6(5):384-92. PMid:27709007

26. Hassan H, Hongli G, Yousef B, Luyong Z, Jiang Z. Hepatotoxicity mechanisms of isoniazid: A mini-review. J Appl Toxicol. 2015;35(12):1427-32. https://doi.org/10.1002/jat.3175 PMid:26095833

27. Elvira-Torales LI, García-Alonso J, Periago-Castón MJ Nutritional importance of carotenoids and their effect on liver health: A review. Antioxidants (Basel). 2019;8(7):229. https:// doi.org/10.3390/antiox8070229

PMid:31330977 